Article

\title{
Assessment of Flood Frequency Alteration by Dam Construction via SWAT Simulation
}

\author{
Jeong Eun Lee ${ }^{1,2}$, Jun-Haeng Heo ${ }^{2, *}$, Jeongwoo Lee ${ }^{1}$ and Nam Won Kim ${ }^{1}$ \\ 1 Hydro Science and Engineering Research Institute, Korea Institute of Civil Engineering and Building \\ Technology (KICT), Goyang 10223, Korea; jeus22@kict.re.kr (J.E.L); ljw2961@kict.re.kr (J.L.); \\ nwkim@kict.re.kr (N.W.K.) \\ 2 School of Civil and Environmental Engineering, Yonsei University, Seoul 03722, Korea \\ * Correspondence: jhheo@yonsei.ac.kr; Tel.: +82-2-2123-2805; Fax: +82-2-364-5300
}

Academic Editor: Ataur Rahman

Received: 29 December 2016; Accepted: 5 April 2017; Published: 8 April 2017

\begin{abstract}
The purpose of this study is to evaluate the impacts of the upstream Soyanggang and Chungju multi-purpose dams on the frequency of downstream floods in the Han River basin, South Korea. A continuous hydrological model, SWAT (Soil and Water Assessment Tool), was used to individually simulate regulated and unregulated daily streamflows entering the Paldang Dam, which is located at the outlet of the basin of interest. The simulation of the regulated flows by the Soyanggang and Chungju dams was calibrated with observed inflow data to the Paldang Dam. The estimated daily flood peaks were used for a frequency analysis, using the extreme Type-I distribution, for which the parameters were estimated via the L-moment method. This novel approach was applied to the study area to assess the effects of the dams on downstream floods. From the results, the two upstream dams were found to be able to reduce downstream floods by approximately $31 \%$ compared to naturally occurring floods without dam regulation. Furthermore, an approach to estimate the flood frequency based on the hourly extreme peak flow data, obtained by combining SWAT simulation and Sangal's method, was proposed and then verified by comparison with the observation-based results. The increased percentage of floods estimated with hourly simulated data for the three scenarios of dam regulation ranged from $16.1 \%$ to $44.1 \%$. The reduced percentages were a little higher than those for the daily-based flood frequency estimates. The developed approach allowed for better understanding of flood frequency, as influenced by dam regulation on a relatively large watershed scale.
\end{abstract}

Keywords: SWAT; regulated and unregulated streamflows; flood frequency analysis; sangal's method

\section{Introduction}

Growing industrial, municipal, and agricultural demands for water have increased the need for dam construction [1]. Numerous dams have been built in the majority of the world's rivers to provide water supply, electricity production, and the mitigation of flood risk. River hydrology, geomorphology, and ecology have been substantially altered through dam construction. In particular, dams have major impacts on river hydrology, primarily through changes in the timing, magnitude, and frequency of high and low flows, ultimately producing a hydrologic regime that differs significantly from the natural pre-dam conditions [2-4].

Various studies dealing with downstream hydrograph alterations caused by dams have been undertaken. For example, Gregory and Park [5] examined the changed pattern of river discharge and channel capacity below a dam in the basin of the River Tone, England. Their results showed that the downstream peak discharge was reduced by $40 \%$ after the dam construction, and the reduction of channel capacity downstream from the reservoir persisted for a distance of $11 \mathrm{~km}$. Page [6] 
demonstrated that the construction of the Burrinjuck Dam increased the return period of bankfull discharge in Wagga Wagga, Australia. Galat and Lipkin [7] studied the hydrological alterations of the Missouri River flows using the Index of Hydrological Alteration (IHA), indicating that the river flows were heavily influenced by the reservoirs, but they dissipated below tributary junctions. Maingi and Marsh [8] analyzed pre- and post-dam daily discharge data for the Tana River, Kenya, using flood frequency analysis and the computation of various IHAs, demonstrating a significant modification in the hydrologic regime after dam construction. They also estimated the frequency and duration of floods for 71 vegetation sample plots by simulating the hydrologic water profiles, showing an increase in days flooded from the pre- to the post-dam period. Magilligan et al. [9] assessed hydrologic changes at 21 dams of various sizes scattered across the U.S., and found that on average the 2-year flow decreased by $60 \%$ after dam installation [10]. Pegg et al. [11] used a time series approach to examine the daily mean flow for 10 Missouri River locations with data from the pre- and post-alteration periods. The results suggest that human alterations on the Missouri River, particularly in the middle portion that is most strongly affected by impoundments and channelization, have resulted in changes to the natural flow regime. Batalla et al. [12] investigated how hydrograph alteration from dams varies though the river network, and determined that the influence of dams on mean monthly flow and flood magnitude diminished with the distance downstream because of increasing drainage area. Magilligan and Nislow [13] presented an analysis of pre- and post-dam hydrological changes from dams that cover the spectrum of hydrologic and climatic regimes across the U.S. They applied the IHA to assess the type, magnitude, and direction of hydrologic shifts for 21 gauge stations due to dam installation, and found that 1-day through 90-day minimum flows increased significantly, while 1-day though 7-day maximum flows decreased significantly following impoundment. Singer [14] reported basinwide patterns of hydrograph alteration via statistical and graphical analysis from a network of long-term streamflow gauges in the Sacramento River basin in California, U.S. In this study, pre- and post-dam flows were compared with respect to the annual flood peak, annual flow trough (lowest value), annual flood volume, time to peak, flood drawdown time, and interarrival time. Yang et al. [1] investigated the spatial patterns of the hydrologic alterations caused by dam construction in the middle and lower Yellow River, China during the most recent five decades using the range of variability approach (RVA) method in which 33 hydrologic parameters were used to assess the hydrologic alterations in terms of streamflow magnitude, timing, frequency, duration, and rate of change. Romano et al. [15] evaluated the pre-dam versus post-dam differences in flood frequency and duration below the Carlyle Dam, lower Kaskaskia River, U.S. The results indicated a decrease in flood duration and frequency, and a decrease in annual flood frequency variation at a near site below the dam. However, their results also showed that hydrological alterations were related to climate rather than dam effects at a far distance downstream from the dam, emphasizing that the distance downstream from the dam and downstream tributary and watershed characteristics should be considered. These works mentioned above have indicated that dams appear to decrease flood peaks and increase low flows. However, these have all focused only on comparing pre- and post-dam flows with respect to the hydrograph characteristics of frequency, magnitude, and shape; they do not focus on naturalized flow conditions that would have existed before dam construction without the effect of regulation.

Some investigations have compared historical regulated flow data with natural flow data generated by rainfall-runoff modeling to assess the impacts of dams on flood flows. The U.S. Geological Survey (USGS) $[16,17]$ has published reports evaluating the effects of flood detention reservoirs on flood frequencies, as well as peak discharges along downstream reaches for several small urban drainage basins with areas of 0.1-0.37 square miles in Georgia, U.S. In the study, the Distributed Routing Rainfall-Runoff Model (DR3M), developed by the USGS, was used to simulate the long-term peak discharges for conditions with and without the flood detention reservoirs. The relationships of flood-frequency, between those with and without reservoirs, were developed based on these long-term peak discharges. Peters and Prowse [18] quantified the effects of regulation on the Peace River, Canada, based on comparisons between pre-regulated, regulated, and naturalized flow regimes. 
In their work, a modified Streamflow Synthesis and Reservoir Regulation (SSARR) model was used to naturalize the river flows. Montaldo et al. [19] analyzed the flood hydrograph attenuation induced by a reservoir system for the Toce River basin, Italy, using a Flash-flood Event-based Spatially distributed rainfall-runoff Transformation, including Reservoir System (FEST98RS). Sayama et al. [20] developed a rainfall-runoff prediction system for the Yodo River basin, Japan, and demonstrated that the system was able to simulate complex dam operations, such as preliminary release, peak attenuation, and cooperative operations by multiple dams. Gross and Moglen [21] developed regression equations, both natural and with the dam, for predicting the influence distance of flow regulation downstream of a dam using the Geographic Information System (GIS), the HEC (Hydrologic Engineering Center)-1 model, and the stage-storage-discharge curves for 34 dams in Maryland, U.S. All these studies relied on rainfall-runoff modeling to assess the post-dam effects on flood flows. From these reviews, it can be seen that previous studies on the impact of dams and reservoirs have predominantly focused on alterations in the hydrograph. However, none have quantified the effects of regulation on flood frequency, except those conducted by the USGS [16,17]. A possible reason for the lack of studies assessing the effects of dams on flood frequencies during the post-dam period is that generating flood data over a sufficient period of time for a flood frequency analysis is difficult.

Traditionally, flood frequency estimations have been based on statistical analyses using available gauged flood peaks. In cases where long records of measured streamflow data are not available, an estimate of flood frequency must be based on event simulation or continuous simulation modeling. The availability of powerful computers has made it possible to move towards techniques for flood estimation based on continuous simulation modeling [22]. Since the late 1990s, the estimation of flood frequency was approached using the continuous simulation of stream flow time series [23-31]. The main advantages of this approach are that the streamflow can be considered as a single term, without explicit prior separation into direct runoff and baseflow, and the problem associated with the antecedent wetness condition, which is very important in the consideration of event simulation, is largely removed because this condition is an integral part of the modeling procedure [23]. Furthermore, other merits of using a continuous simulation model to simulate streamflow include: the use of longer data series for the frequency analysis, the ability to simulate streamflow under future land use/climate conditions, and no assumption of a direct transformation of a design rainfall to a design flood [25]. These advantages of continuous simulation modeling make it possible to more elaborately explore various hydrological problems.

Therefore, the objective of this study is to investigate the potential of a continuous simulation model for assessing the effects of a dam on the characteristics of downstream flood frequencies. A continuous simulation model, SWAT (Soil and Water Assessment Tool), was used to predict the stream flow time series, both with and without dams, which were then analyzed to produce flood frequency curves. The SWAT model was developed by the U.S. Department of Agriculture (USDA) Agricultural Research Service and is a quasi-distributed model used for simulating runoff at the watershed scale $[32,33]$. The reasons for selecting the SWAT model include its wide global use and good performance for predicting daily runoff hydrographs. Moreover, the model is an open source code program; thus, it can be modified to improve its performance. This paper outlines the overall procedure of the SWAT-simulation-based flood frequency estimation and discusses the results of the impacts of the upstream Soyanggang and Chungju multi-purpose dams on the flood frequency of downstream flows in the Han River basin, South Korea. 


\section{Methodology}

\subsection{SWAT Model Description}

The SWAT model was developed as a watershed scale hydrological model for assessing the effects of land use and management on the long-term runoff, sediment, and non-point source pollution loads to surface water bodies on a daily basis. The major components of SWAT include: weather, hydrology, erosion, plant growth, nutrients, pesticides, land management, and streamflow routing. The methods for estimating the hydrological components are briefly described below. The model allows for simulation with high level spatial detail by dividing the watershed into multiple sub-watersheds, which are then partitioned into additional areas, called Hydrologic Response Units (HRUs). The water in each HRU is stored in or released from four storage volumes: snow, soil profile, shallow aquifer, and deep aquifer. Snow melts on days when the maximum temperature exceeds a preselected threshold value. Melted snow is treated as rainfall for estimating the amount of runoff and percolation. The soil profile is subdivided into multiple layers for soil water processes, such as infiltration, evaporation, plant uptake, lateral flow, and percolation. Surface runoff or infiltration from daily rainfall is calculated using a modified Soil Conservation Service (SCS) Curve Number (CN) method, or is otherwise calculated using the Green-Ampt method. The model individually computes the evaporation from soils and transpiration from plants. Potential evapotranspiration (PET) can be calculated using the Penman-Monteith, Priestley-Taylor, or Hargreaves methods. Potential soil water evaporation is estimated using a function of the PET and leaf area index. Actual soil evaporation is estimated using exponential functions for the soil depth and water content. Plant water uptake is simulated by a linear function of the PET, leaf area index, and root depth, and is limited by the soil water content. The soil percolation component is estimated using a water storage capacity technique, in which downward flow occurs when the field capacity of a soil layer is exceeded. The shallow aquifer is recharged by the water from the bottom of the soil profile by the percolation process. Simultaneous to percolation, the lateral sub-surface flow in the soil profile is calculated using the kinematic storage model, which is a function of the saturation hydraulic conductivity, slope length, and slope. The recharge and discharge of groundwater were estimated using exponential attenuation weighting functions. These hydrological components for each HRU are summed over a sub-watershed. The calculated flow obtained for each sub-watershed is then routed through the river channels. Finally channel routing is simulated using the variable storage or Muskingum method. More details can be found in the work of [34].

\subsection{Study Area}

The seven dams located upstream of the Paldang Dam are shown in Figure 1, including: the Soyanggang and Chungju multi-purpose dams, and the Hwacheon, Chuncheon, Uiam, Cheongpyeong, and Goesan dams for electricity generation in the Han River basin. In this study, the impacts of the two major multi-purpose dams, Soyanggang and Chungju, on the downstream flood frequency were assessed at the Paldang Dam. According to [35], the dams for electricity generation (Hwacheon, Chuncheon, Uiam, Cheongpyeong, and Goesan) have little effect on flood control and were therefore not included in this assessment. The Chungju Dam, which was built lastly among the dams considered in this study, was constructed in 1986, therefore, the data period used in this work starts from that year. 


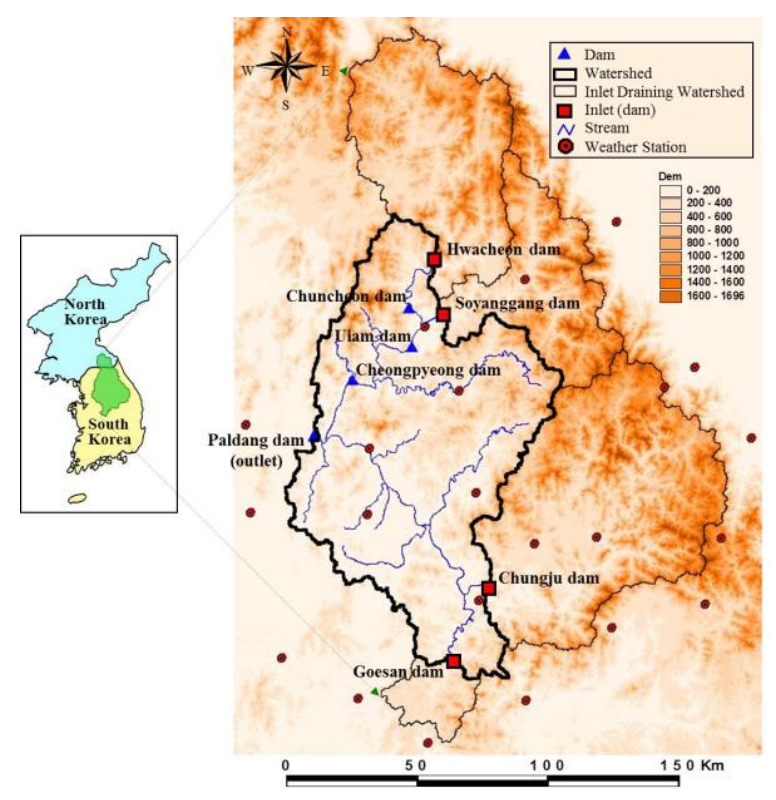

Figure 1. Study area.

\subsection{Approach for Flood Frequency Assessment}

Current inflows to the Paldang Dam are regulated by the upstream multi-purpose dams, Chungju and Soyanggang. Data without the influence of the dams are not available; therefore, a frequency analysis was not possible. The SWAT model allows for daily streamflow estimation, without the influence of the dam, by designating upstream dams as inlet conditions of the model and plugging upstream dam inflows into the inlets. The historical dam inflows can be regarded as unregulated flows below the dams. Therefore, in this study, SWAT simulations were performed to generate streamflows for the conditions without dams; then the simulated streamflow data was used for the flood frequency analysis.

The effects of dams on the peak inflows and flood frequencies at the Paldang Dam were determined by simulating the annual peak flows with and without dams. Annual peak flows for the period 1986-2015 were simulated by the SWAT model. Several scenarios were built based on the presence of dams, and the resulting flood frequencies were compared to each other to characterize the effects of dam regulation on floods. The first simulation was for existing conditions, i.e., with dams in place. Subsequent simulations involved eliminating individual dams to determine the effect of a single dam on the peak flows for the entire basin. The model was also used to simulate conditions without any dams for a basin to examine the cumulative effects of upstream dams on the peak flow at the outlet.

SWAT simulation is based on a daily time step; as such, the SWAT model cannot represent a small time scale, such as hours or minutes, for simulating sharp peaks. To overcome this, Sangal's method was used to estimate the instantaneous peak flow from the mean daily flow. Sangal [36] suggested a practical formula, shown in Equations (1) and (2), based on the assumption of a triangular hydrograph, in which the instantaneous peak flow is estimated from the mean daily flow for three consecutive days, including the peak day.

$$
\begin{gathered}
Q_{\max }=\frac{Q_{1}+Q_{3}}{2}+\frac{2 Q_{2}-Q_{1}-Q_{3}}{K} \\
K=\frac{4 Q_{2}-2 Q_{1}-2 Q_{3}}{2 Q_{\text {peak }}-Q_{1}-Q_{3}}
\end{gathered}
$$

where $Q_{\max }$ is the predicted instantaneous peak flow $\left(\mathrm{m}^{3} / \mathrm{s}\right), Q_{2}$ is the mean daily flow $\left(\mathrm{m}^{3} / \mathrm{s}\right)$ of the day that includes the peak flow, $Q_{1}$ and $Q_{3}$ are the mean daily flow $\left(\mathrm{m}^{3} / \mathrm{s}\right)$ for the days before and 
after the peak flow day, respectively, $K$ is the base factor calculated from the historical mean daily and peak flows, and $Q_{\text {peak }}$ is the actual peak flow $\left(\mathrm{m}^{3} / \mathrm{s}\right)$. Sangal [37] applied this method to streams with drainage areas that varied from less than $1 \mathrm{~km}^{2}$ to more than 100,000 km in Ontario, Canada, using the data of 3946 peak flows collected from a total of 387 stations and achieved results with reasonable accuracies. Also, the base factor $K$ is an important parameter and can be estimated from historical flows. In this study, a reasonable estimate of $K(=0.96)$ is calculated from historical flows at the Paldang Dam.

\section{SWAT Modeling}

\subsection{Input Data and Model Preparation}

The SWAT model is applicable for assessing the effects of dam regulation on downstream floods. Accordingly, the model was used in this study to assess the changes in downstream floods regulated by the upstream multi-purpose dams in the Paldang Dam watershed. As shown in Figure 1, the Soyanggang, Chungju, Hwacheon, and Goesan Dams comprised the model inlets from their respective upstream watersheds. Instead of simulating runoff from the entire watershed, the observed discharges from the Soyanggang and Chungju dams were directly plugged into the model, with runoffs from the remaining watersheds then simulated to determine the flood inflows to the Paldang Dam. This was intended to eliminate errors associated with the runoff simulation for upstream watersheds. In addition, the Chuncheon, Uiam, and Cheongpyeong electricity generation dams that are located in the middle of the study watershed were not considered in the modeling because they are incapable of flood control and discharge all inflows nearly without detention for electricity generation. Therefore, the inflows to the Paldang Dam can be simulated reasonably even though the electricity generation dams were not considered. Table 1 shows the inlet conditions at the upper dams to be implemented. The inflow and outflow for the Soyanggang and Chungju dams in 1990 is illustrated in Figure 2.

Table 1. Inlet Conditions at the Upper Dams.

\begin{tabular}{ccccc}
\hline Scenarios & Soyanggang & Chungju & Hwacheon & Goesan \\
\hline Current state & Outflow & Outflow & Outflow & Outflow \\
Scenario 1 & Inflow & Outflow & Outflow & Outflow \\
Scenario 2 & Outflow & Inflow & Outflow & Outflow \\
Scenario 3 & Inflow & Inflow & Outflow & Outflow \\
\hline
\end{tabular}

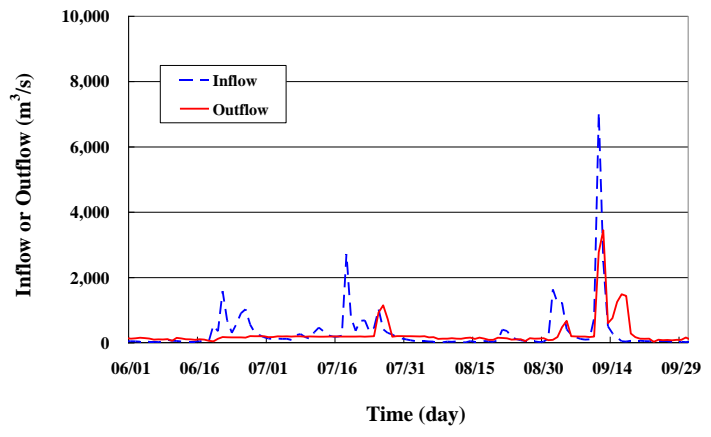

(a)

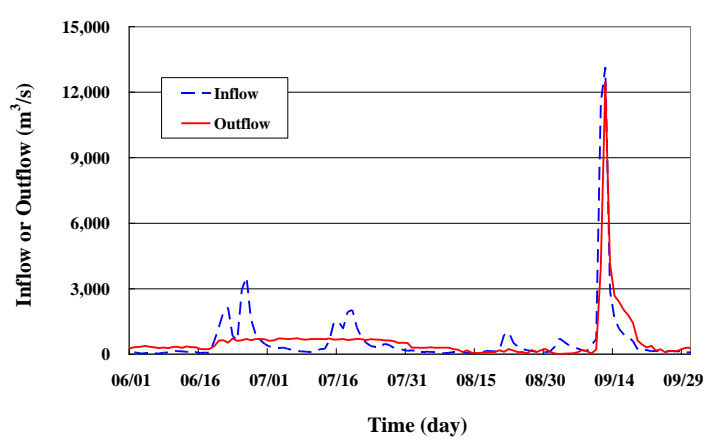

(b)

Figure 2. Inflow and Outflow in 1990. (a) Soyanggang Dam; (b) Chungju Dam.

Daily climatic data of precipitation, solar radiation, maximum/minimum temperature, wind speed, and relative humidity from 1986 to 2015 were used for the SWAT model simulation. A Digital Elevation Model (DEM), with a $100 \mathrm{~m}$ mesh size, mid-classified land cover from the Ministry of Environment, and soil map from the National Institute of Agricultural Sciences were utilized as the 
spatial input data for the model. The entire study watershed was divided into 21 sub-watersheds. The two methods of the temporally weighted average $\mathrm{CN}$ method [37] and non-linear storage routing technique [38] were incorporated into the SWAT model in this study for better simulation of the surface runoff and streamflow routing, respectively. Evapotranspiration was estimated using the Penman-Monteith equation.

\subsection{Model Calibration and Validation}

The parameters of the SWAT model were calibrated using the observed daily inflow data collected from 1986 to 1995 at the Paldang Dam. The parameters were manually adjusted to fit the daily simulations as close as possible to the observations. The statistics of the coefficient of determination $\left(\mathrm{R}^{2}\right)$ and Nash-Sutcliffe efficiency (NSE) [39] were used to evaluate model performances. For a brief description of the calibration procedure, firstly, the soil evaporation compensation coefficient (ESCO) parameter was calibrated to match the total amount of runoff. The other internal parameters were then adjusted for better simulation of the hydrograph, especially for the flows during recession and at peak time. We increased the $\mathrm{CN}$ value with the Antecedent Moisture Condition (AMC)-II condition (CN2) during the flood season (June-September) by $20 \%$ from the default value to increase the peak flow. In addition, we calculated the $\mathrm{CN}$ value of each day using the temporally weighted average $\mathrm{CN}$ method [37]. The $\mathrm{CH} \_\mathrm{N}$ (Manning's n) parameter related to the channel routing was estimated as 0.030 using the non-linear storage routing technique [38], which is higher than the default value, in consideration of the natural channel condition and reliability of the value estimated. The two parameters of average slope length for the subbasin (SLSUBBSN) and adjustment factor for the lateral flow (ADJF), which are related to the interflow generation, were then calibrated. The delay of groundwater recharge (GW_DELAY) parameter was adjusted to generate a reasonable shape of the recession hydrograph. Table 2 shows a list of the calibration parameters and their optimal values.

Table 2. Calibrated model parameters.

\begin{tabular}{ccc}
\hline Parameter & Description & Calibrated Value \\
\hline ESCO & Soil evaporation compensation factor & 0.65 \\
CN2 & CN value with the AMC-II & $+20 \%$ \\
CH_N & Manning's n & 0.03 \\
ADJF & Adjustment factor for lateral flow (default $=1)$ & 2 \\
SLSUBBSN & Average slope length for subbasin (m) & Max (10, default) \\
GW_DELAY & Groundwater delay (days) & 150 \\
\hline
\end{tabular}

Figure 3a shows a good agreement between the observed and simulated daily runoff for the calibration period of 1986-1995. The model performance statistics of $R^{2}$ and NSE using the optimal parameter values for the calibration period were satisfactory, at more than 0.85 . The calibrated parameter values were then applied to the SWAT model to simulate the flow time series of the validation period of 1996-2015 to evaluate the model prediction ability. Figure 3b shows a good model performance with $\mathrm{R}^{2}$ and NSE values greater than 0.85 . It reveals that the hydrologic processes were reasonably modeled by the SWAT model. 


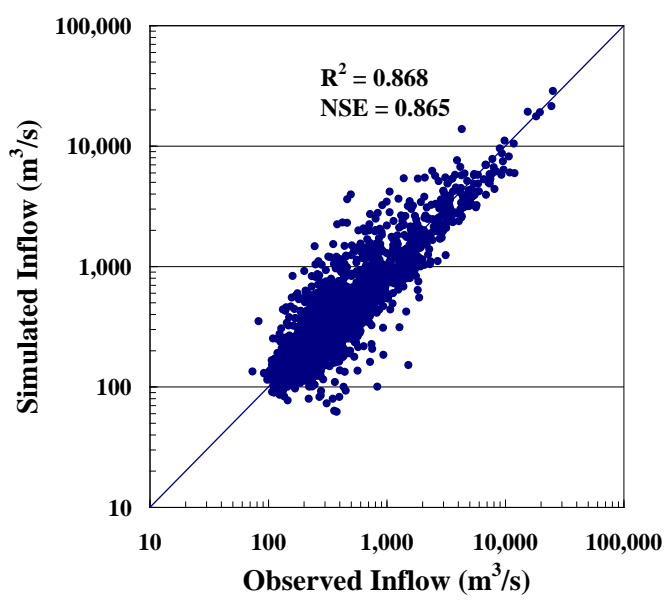

(a)

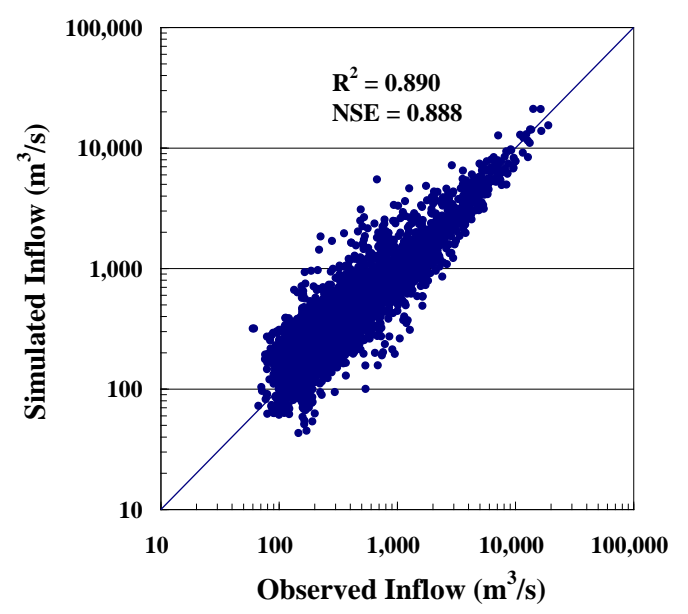

(b)

Figure 3. Comparison of the observed and simulated inflows to the Paldang Dam for (a) calibration period (1986-1995) and (b) validation period (1996-2015).

\subsection{Model Results}

The runoff ratio, flow duration curve, and daily streamflow discharge simulated by SWAT were analyzed at the Paldang Dam. The runoff ratio is defined as the runoff volume divided by the rainfall volume that occurred during the flood season (June-September) of each year. Table 4 contains the observed and simulated runoff ratios from 1986 to 2015, as well as the statistical values of $R^{2}$ between the simulated and observed daily flows. The results are highly acceptable.

Table 3. Runoff ratio and Determination coefficient.

\begin{tabular}{ccccccc}
\hline \multirow{2}{*}{ Year } & \multirow{2}{*}{$\begin{array}{c}\text { Rainfall } \\
(\mathbf{m m})\end{array}$} & \multicolumn{2}{c}{ Runoff $(\mathbf{m m})$} & \multicolumn{2}{c}{ Runoff Ratio $\mathbf{( \% )}$} & \multirow{2}{*}{$\begin{array}{c}\text { Determination } \\
\text { Coefficient }\end{array}$} \\
\cline { 3 - 5 } & & Observed & Simulated & Observed & Simulated & \\
\hline 1986 & 788.9 & 378.0 & 357.9 & 47.9 & 45.4 & 0.795 \\
1987 & 1206.4 & 940.1 & 865.5 & 77.9 & 71.7 & 0.867 \\
1988 & 712.8 & 374.6 & 398.5 & 52.5 & 55.9 & 0.849 \\
1989 & 850.7 & 334.8 & 372.1 & 39.4 & 43.7 & 0.733 \\
1990 & 1545.5 & 1128.7 & 1040.7 & 73.0 & 67.3 & 0.856 \\
1991 & 925.4 & 421.9 & 429.0 & 45.6 & 46.4 & 0.722 \\
1992 & 719.7 & 249.7 & 277.1 & 34.7 & 38.5 & 0.709 \\
1993 & 797.8 & 508.1 & 481.1 & 63.7 & 60.3 & 0.745 \\
1994 & 687.7 & 220.9 & 261.8 & 32.1 & 38.1 & 0.721 \\
1995 & 1236.1 & 822.6 & 750.4 & 66.5 & 60.7 & 0.904 \\
1996 & 715.7 & 370.3 & 365.0 & 51.7 & 51.0 & 0.854 \\
1997 & 730.4 & 458.6 & 386.2 & 62.8 & 52.9 & 0.729 \\
1998 & 1276.0 & 726.0 & 702.9 & 56.9 & 55.1 & 0.877 \\
1999 & 1108.3 & 580.2 & 610.5 & 52.4 & 55.1 & 0.854 \\
2000 & 926.1 & 424.3 & 449.5 & 45.8 & 48.5 & 0.770 \\
2001 & 753.5 & 285.7 & 311.6 & 37.9 & 41.4 & 0.798 \\
2002 & 926.0 & 465.0 & 537.0 & 50.2 & 58.0 & 0.934 \\
2003 & 1277.0 & 724.2 & 717.5 & 56.7 & 56.2 & 0.842 \\
2004 & 1051.5 & 614.4 & 628.4 & 58.4 & 59.8 & 0.864 \\
2005 & 1209.1 & 527.0 & 501.0 & 43.6 & 41.4 & 0.749 \\
2006 & 1242.3 & 732.2 & 756.6 & 58.9 & 60.9 & 0.971 \\
2007 & 1027.9 & 589.7 & 525.8 & 57.4 & 51.1 & 0.960 \\
2008 & 909.5 & 374.3 & 373.2 & 41.2 & 41.0 & 0.941 \\
2009 & 1013.4 & 487.4 & 459.0 & 48.1 & 45.3 & 0.925 \\
2010 & 1074.0 & 477.4 & 436.2 & 44.4 & 40.6 & 0.914 \\
\hline
\end{tabular}


Table 4. Runoff ratio and Determination coefficient.

\begin{tabular}{ccccccc}
\hline \multirow{2}{*}{ Year } & \multirow{2}{*}{$\begin{array}{c}\text { Rainfall } \\
(\mathbf{m m})\end{array}$} & \multicolumn{2}{c}{ Runoff $(\mathbf{m m})$} & \multicolumn{2}{c}{ Runoff Ratio (\%) } & \multirow{2}{*}{$\begin{array}{c}\text { Determination } \\
\text { Coefficient }\end{array}$} \\
\cline { 3 - 5 } & & Observed & Simulated & Observed & Simulated & \\
\hline 2011 & 1568.8 & 919.7 & 903.4 & 58.6 & 57.6 & 0.974 \\
2012 & 990.0 & 405.9 & 382.6 & 41.0 & 38.6 & 0.870 \\
2013 & 1050.5 & 548.9 & 496.5 & 52.3 & 47.3 & 0.964 \\
2014 & 494.9 & 125.7 & 144.0 & 25.4 & 29.1 & 0.914 \\
2015 & 395.8 & 86.5 & 91.0 & 21.8 & 23.0 & 0.980 \\
\hline Average & 973.7 & 510.1 & 500.4 & 50.0 & 49.4 & 0.828 \\
\hline
\end{tabular}

From the simulated daily flows, the exceedance probability of the flow, referred to as the flow duration curve, was plotted with that based on the observed data, as shown in Figure 4. In can be seen that all sections of the high, intermediate, and low flows were simulated with reasonable accuracy.

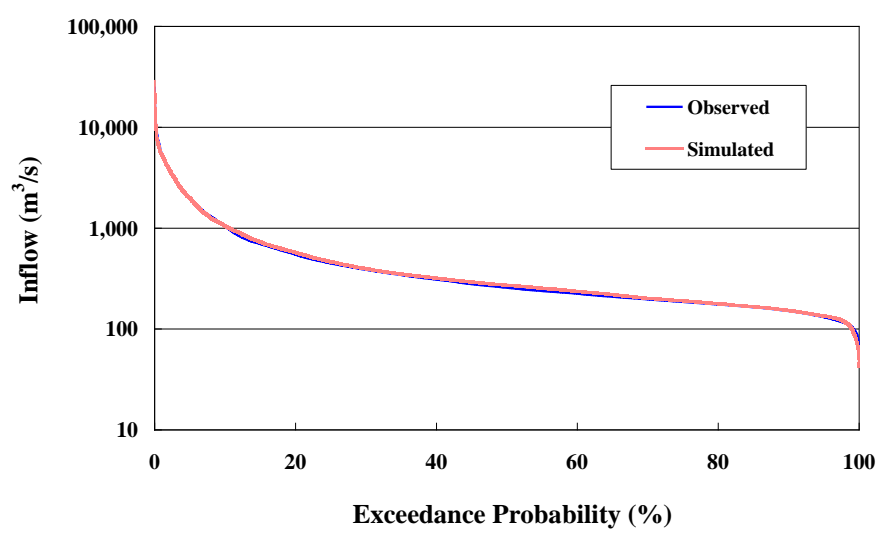

Figure 4. Observed and Simulated Flow Duration Curve at the Paldang Dam.

Figure 5 compares the hydrographs of the observed and simulated daily inflows to the Paldang Dam for large, mid, and low flood years between 1986 and 2015. The simulated inflows matched well with the observed inflows (average $\mathrm{R}^{2}=0.828$ in Table 4 ).
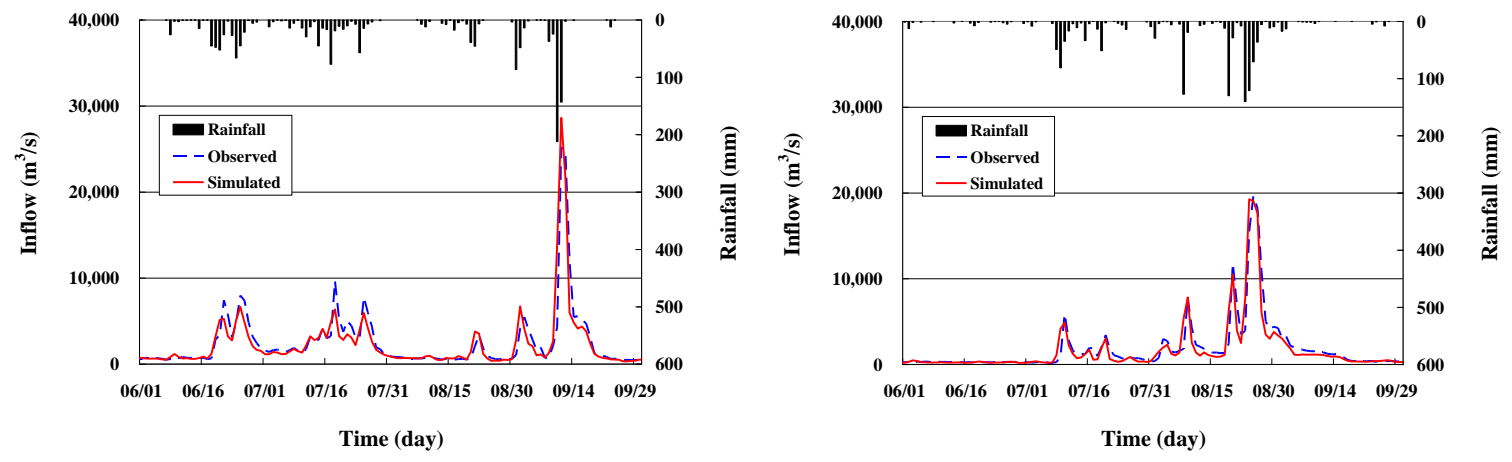

(a)

Figure 5. Cont. 

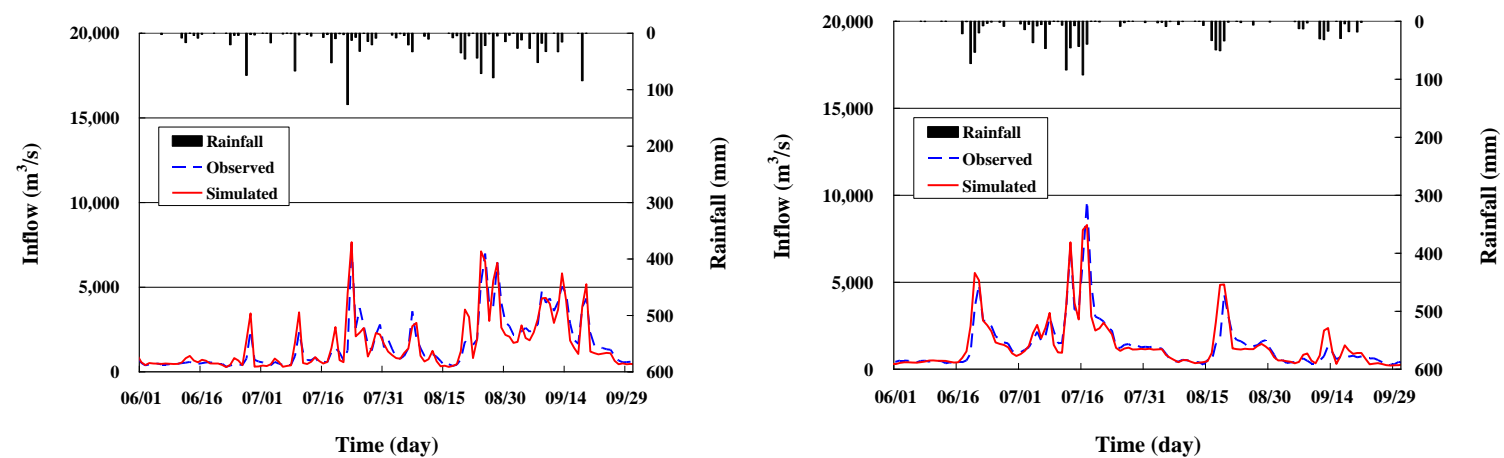

(b)
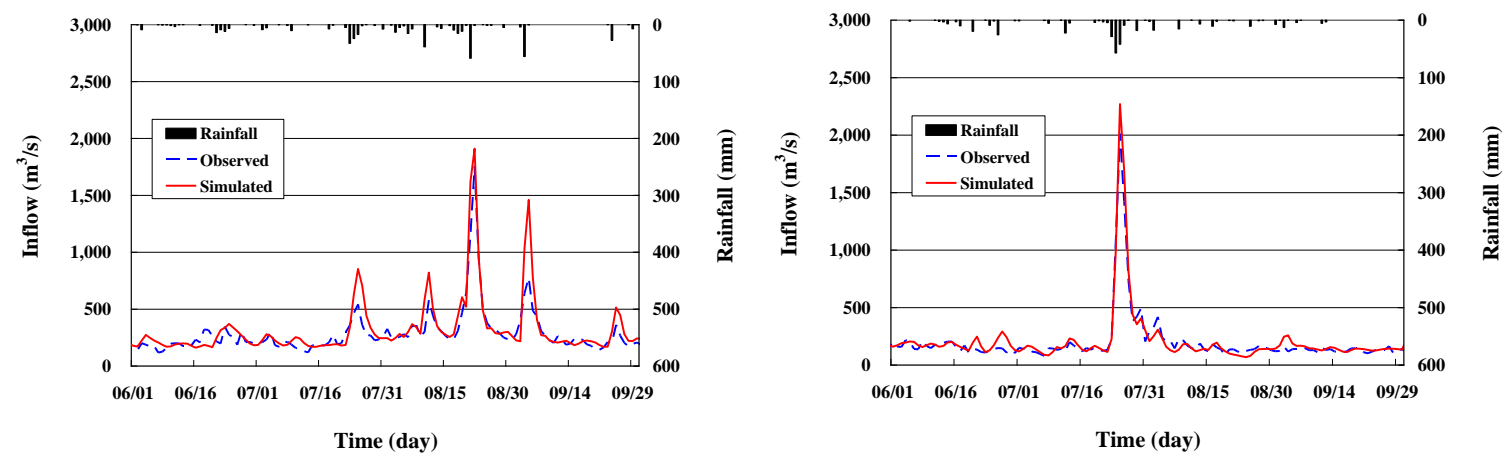

(c)

Figure 5. Observed and Simulated Daily Inflow at the Paldang Dam. (a) Large flood years (left: 1990, right: 1995); (b) Mid flood years (left: 2003, right: 2004); (c) Low flood years (left: 2014, right: 2015).

\section{Results and Discussion}

\subsection{Flood Frequency Analysis of the Observed and Simulated Daily Inflows}

The annual maximum series of simulated and observed inflows at the Paldang Dam were extracted from the simulated and observed hydrographs. Comparisons between the annual maximum series of simulated and observed inflows for the study period (Figure 6) showed the robustness of the SWAT simulation $\left(\mathrm{R}^{2}=0.903\right.$, Root Mean Square Error $\left.(\mathrm{RMSE})=0.187 \mathrm{~m}^{3} / \mathrm{s}\right)$.

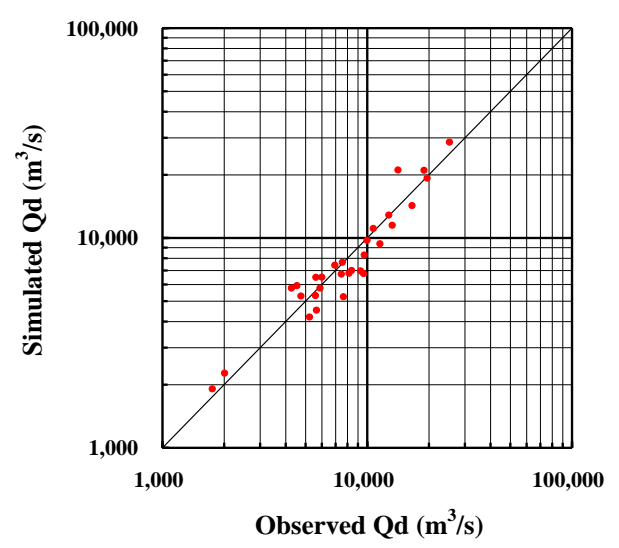

Figure 6. Annual Maximum Series of Observed and Simulated Daily Inflow. 
A flood frequency analysis was performed on the annual maximum series of simulated and observed daily peak inflows at the Paldang Dam. The data used is shown in Figure 6. In this study, the probability distribution of Extreme Value Type-I was selected for the flood frequency analysis, with the relevant parameters estimated using the method of L-moments, as described by [40]. A comparison of flood estimates and frequencies computed from both the simulated and observed data is shown in Figure 7. Comparing the observed and simulated flood estimates, the flood estimates based on the simulated streamflow were slightly overestimated compared to the observed data. The overall errors ranged from $-1.84 \%$ to $3.18 \%$. This small error suggests satisfactory correspondence between the simulated and observed flood frequencies.

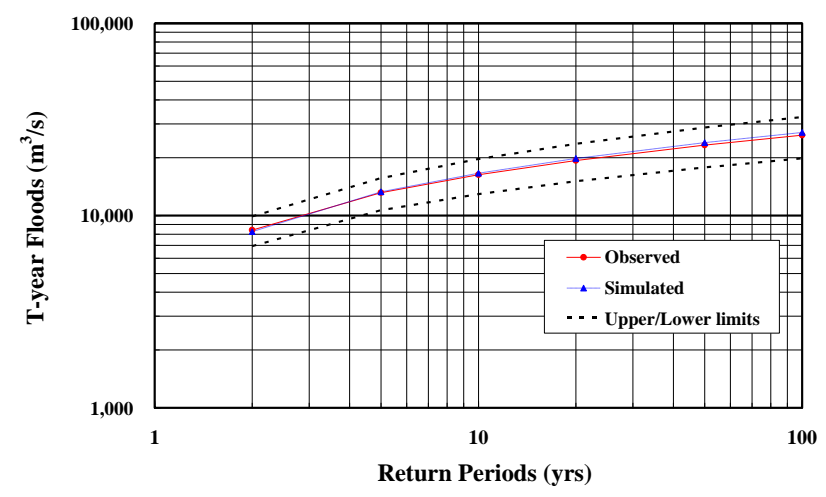

Figure 7. Observed and Simulated T-year Floods at the Paldang Dam (Daily).

\subsection{Influence of Regulated Flow by the Dam on Daily Flood Frequency}

The inflows to the Paldang Dam, under the regulation of the upstream dams, were evaluated in the previous section. To assess the dam effects on the flood frequency, flood flows into the Paldang Dam without upstream dam regulation need to be estimated and compared with regulated floods. Three scenarios were constructed for the unregulated flood simulation based on the existence of an individual dam: Scenario 1 (Chungju dam only), Scenario 2 (Soyanggang dam only), and Scenario 3 (no dam), as shown in Table 1. The runoff from all watersheds without any dam (Scenario 3) was simulated to estimate the unregulated floods to the Paldang Dam. Similar to the regulated flow simulation, the measured outflows or inflows of each dam were used as inlets to the model. The measured outflow or inflows were subjected to flow directly to the downstream channel of each dam for the watersheds with a dam, i.e., the Soyanggang and Chungju dams, for Scenarios 1 and 2.

Figure 8 shows a comparison of the hydrographs for the current state with the Chungju and Soyanggang dams (w/CJ, SY) and the three scenarios for 1990, 1995, 1999, and 2006, where high flood peaks occurred. It was obvious that regulation resulted in a marked reduction in discharges. For example, between Scenario 3 (natural flow condition; w/o CJ, SY) and the current state, the peaks were reduced by an average of $30.9 \%$ for the years studied.

Figure 9 depicts the simulated annual maximum series of inflows for the three scenarios at the Paldang Dam from 1986 to 2015 . As expected, the modeled peaks for the three scenarios were higher than those found in the historical records for the current state with the effects of the Soyanggang and Chungju multi-purpose dams. In Figure 9, the slopes indicate the degree of increase in the peaks. Disregarding the effects of the dams on the peak attenuation would lead to considerably larger design flood estimates. 


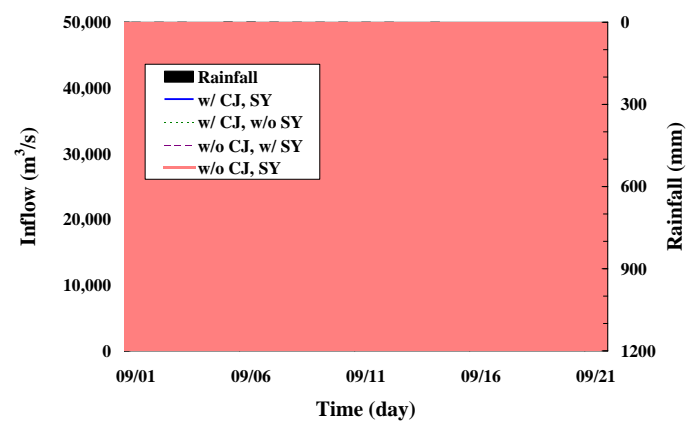

(a)

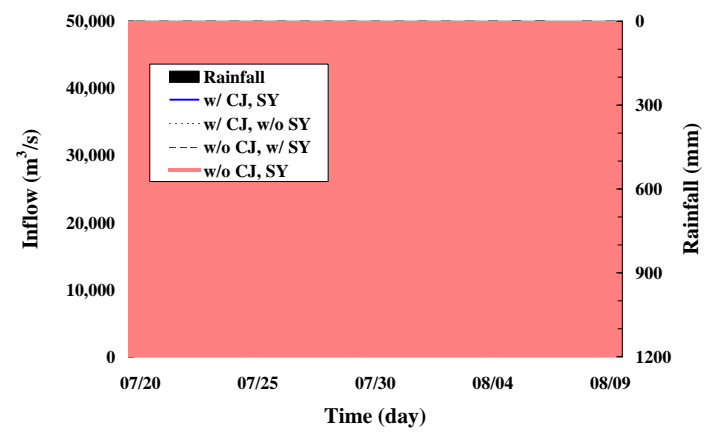

(c)

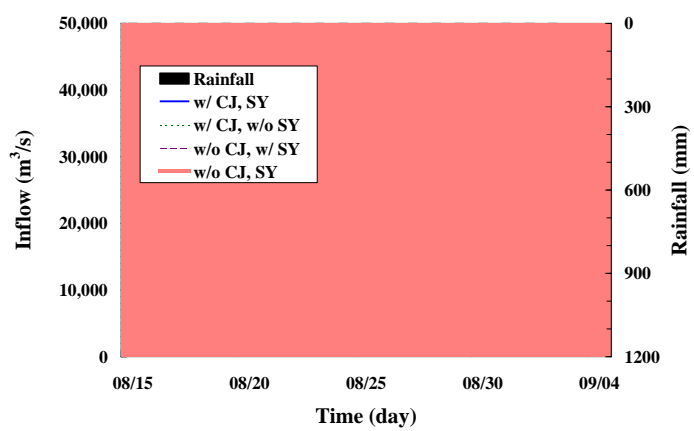

(b)

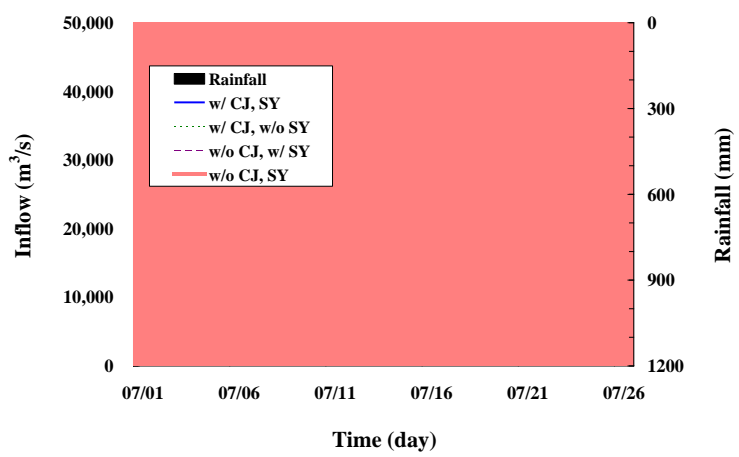

(d)

Figure 8. Hydrographs according to the Scenarios at the Paldang Dam. (a) 1990; (b) 1995; (c) 1999; (d) 2006 .

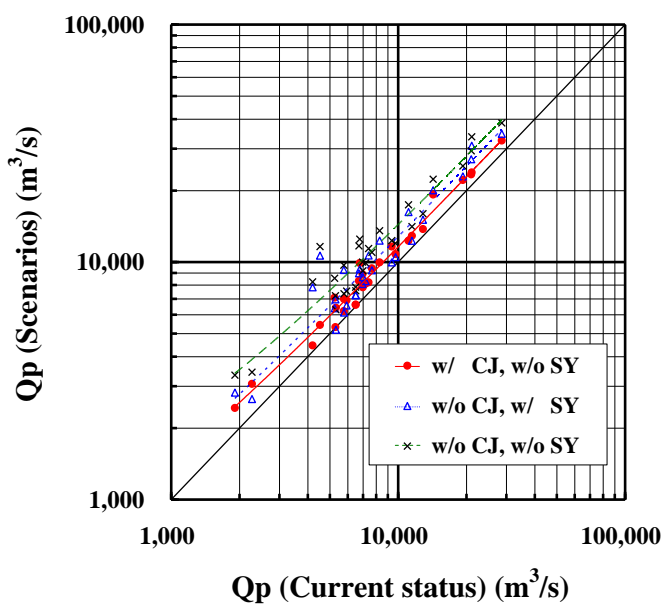

Figure 9. Annual Maximum Series according to the Scenarios (Daily).

Figure 10 presents the flood frequency for each scenario. Natural (Scenario 3) and regulated (Scenario 1, 2, current) flood frequency curves indicated similar patterns for all scenarios. The discrepancy between the flood with and without the dams indicates the effect of regulation by the dam. Assuming Scenario 3 represents the flood frequency under natural conditions, the regulated flood frequencies estimated from the current state and Scenarios 1 and 2 were $70.1 \%, 81.2 \%$, and $90.1 \%$ of the natural flood, respectively. The 100 -year flood under the current state $\left(27,050 \mathrm{~m}^{3} / \mathrm{s}\right)$ appeared to be equivalent to the natural flood, with 10 to 20 -year return periods, which implies the substantial effect of the dam on flood regulation. The percentage increases expected in the flood estimates for Scenarios 1, 2, and 3 for the return periods of 2, 5, 10, 20, 50, and 100 years without dams are listed in Table 5. The data presented in Table 5 reveal that the removal of the Soyanggang Dam 
from the basin would increase flood peaks by $15.6 \%$ to $16.5 \%$, the removal of the Chungju Dam would increase flood peaks by $28.5 \%$ to $28.7 \%$, and the removal of both dams would increase floods by $41.5 \%$ to $45.4 \%$. The effect of the Chungju Dam on the flood peak attenuation was about twice that of the Soyanggang Dam. This difference in the effects of dams on flood peaks can be attributed to the dam size and stage-outflow in relation to each dam.

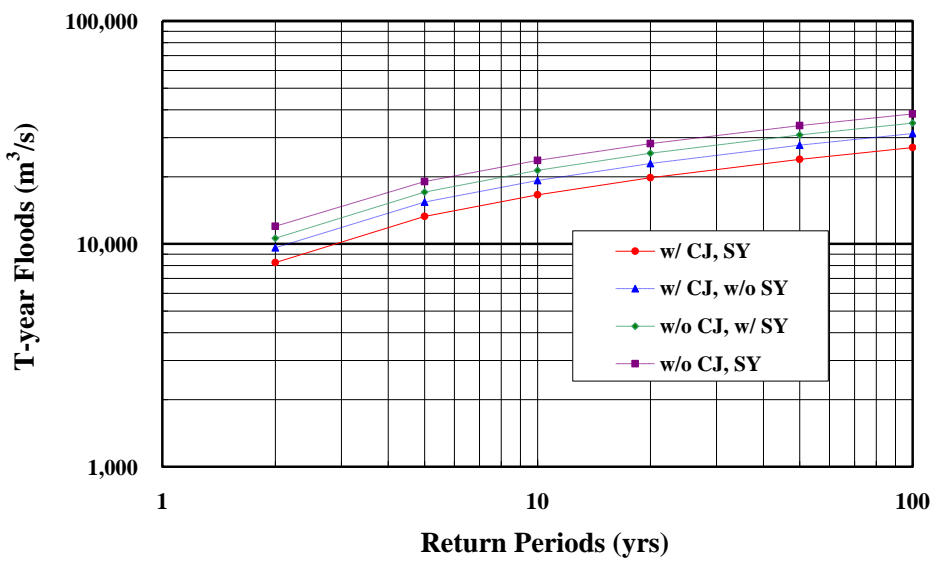

Figure 10. Flood Change for different Return Periods according to the Scenarios (Daily). T-year represents the different return period.

Table 5. Percent Increase in T-year Floods according to the Scenarios (Daily) (\%).

\begin{tabular}{cccccccc}
\hline \multirow{2}{*}{ Scenarios } & \multicolumn{8}{c}{ Return Periods (Years) } \\
\cline { 2 - 8 } & $\mathbf{2}$ & $\mathbf{5}$ & $\mathbf{1 0}$ & $\mathbf{2 0}$ & $\mathbf{5 0}$ & $\mathbf{1 0 0}$ & Ave. \\
\hline Scenario 1 & 16.5 & 16.0 & 15.9 & 15.8 & 15.7 & 15.6 & 15.9 \\
Scenario 2 & 28.5 & 28.6 & 28.6 & 28.6 & 28.6 & 28.7 & 28.6 \\
Scenario 3 & 45.4 & 43.3 & 42.6 & 42.1 & 41.7 & 41.5 & 42.7 \\
\hline
\end{tabular}

\subsection{Influence of Regulated Flow by the Dam on the Hourly Flood Frequency}

Knowledge of instantaneous peak flows is often required to estimate or assess the design flood for hydraulic structures, such as dams and levees, because there may be significant streamflow variations within hours, especially for small basins. For the basin of interest in this study, the annual maximum hourly and daily peak inflow data observed at the Paldang Dam from 1986 to 2015 are plotted in Figure 11. The mean ratio of annual maximum hourly to daily peaks was 1.47 , which indicates that the use of mean daily data may cause underestimation of the design flood.

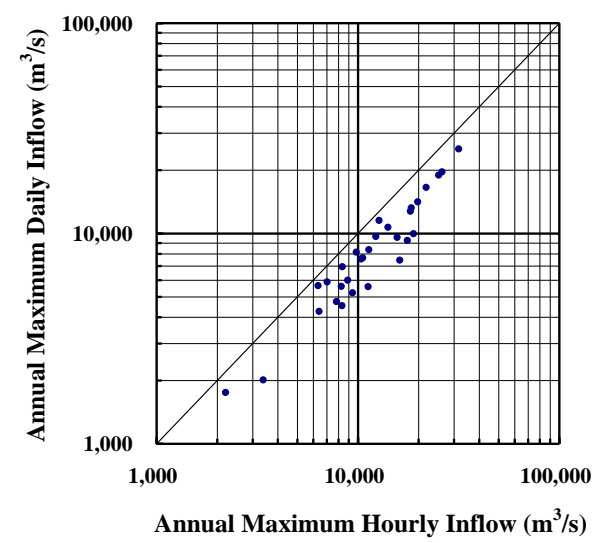

Figure 11. Annual Maximum Series of Hourly and Daily Observed Inflow at the Paldang Dam. 
Figure 12 shows the comparison of flood frequency curves based on the observed daily and hourly annual extreme data. The ratios of hourly to daily floods were calculated for return periods of 2, 5, 10, 20,50 and 100 years, which resulted in an average of approximately 1.39 . It is obvious that there was a significant difference between the hourly and daily peaks; therefore, it is necessary to use small time scale peak flow data for a precise flood frequency assessment.

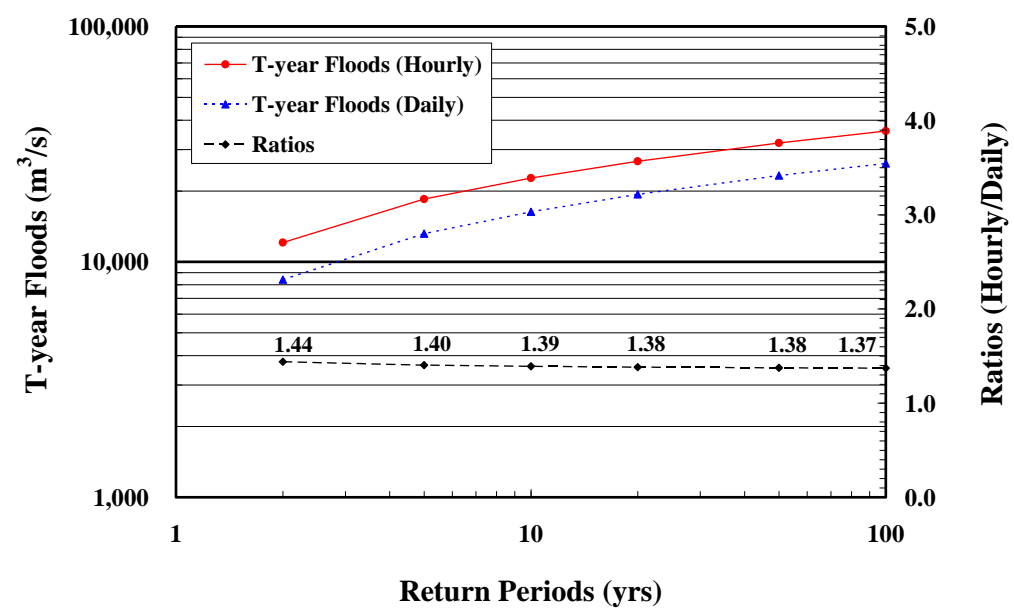

Figure 12. Comparison of the Hourly and Daily Frequency Curve at the Paldang Dam.

To test the validity of Sangal's method for predicting the instantaneous peak flow at the Paldang Dam, a comparison between the observed and estimated hourly peak flows was conducted, the results of which are shown in Figure 13. The estimated values of the hourly peak flow presented a RMSE of less than 0.170 . The $\mathrm{R}^{2}$ value between the observed and estimated data was 0.882 , which represents a high correlation. From these statistical values, it was concluded that Sangal's method is reasonable for estimating the hourly peak flows at the Paldang Dam, the outlet of the study area.

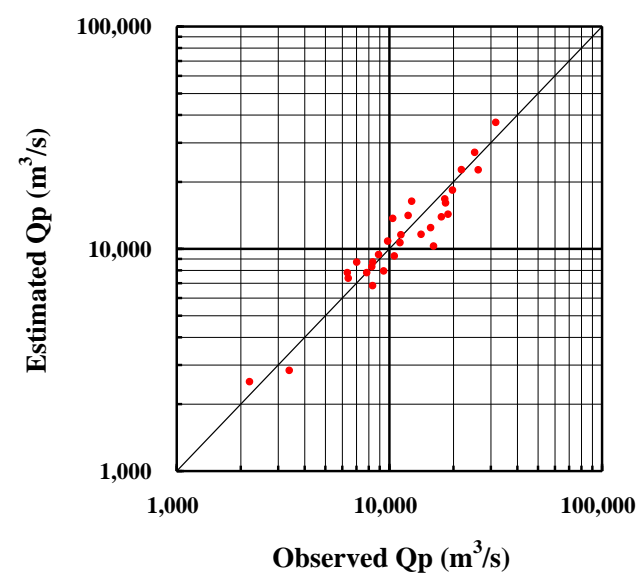

Figure 13. Annual Maximum Series of Observed and Estimated Peak Inflow at the Paldang Dam.

The daily flow peaks simulated by SWAT were converted to hourly flow peaks using Sangal's method, and a series of annual maximum hourly peak flows was then constructed for a flood frequency analysis (Figure 14). 


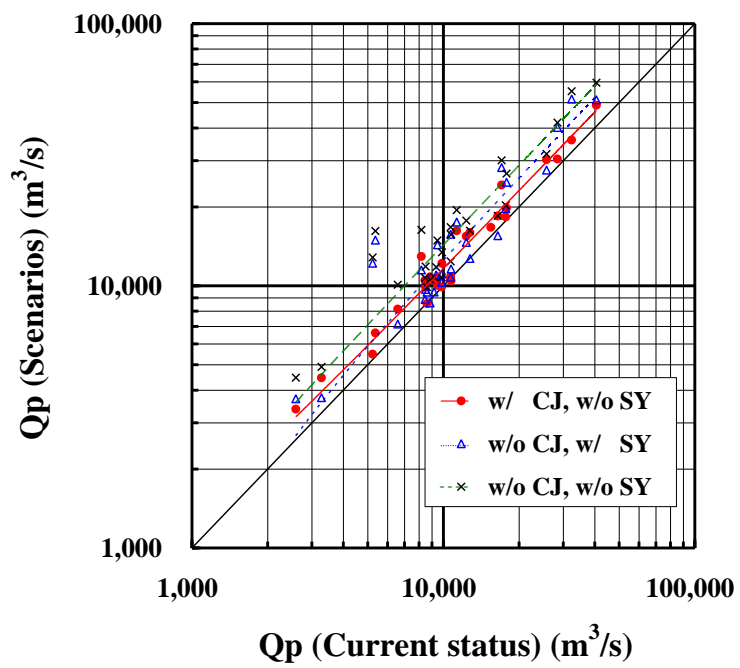

Figure 14. Annual Maximum Series according to the Scenarios (Hourly).

The flood frequency estimates based on hourly data, obtained by combining the SWAT simulation and Sangal's method, were compared with the observation-based results, as shown in Figure 15. Flood frequency estimates based on the simulated data were slightly overestimated, but the errors for return periods of $2,5,10,20,50$, and 100 years were less than $8 \%$ (ranged from $-2.49 \%$ to $7.13 \%$ ). Therefore, the combination of the SWAT simulation and Sangal's method is suitable for estimating small time scale flood peaks.

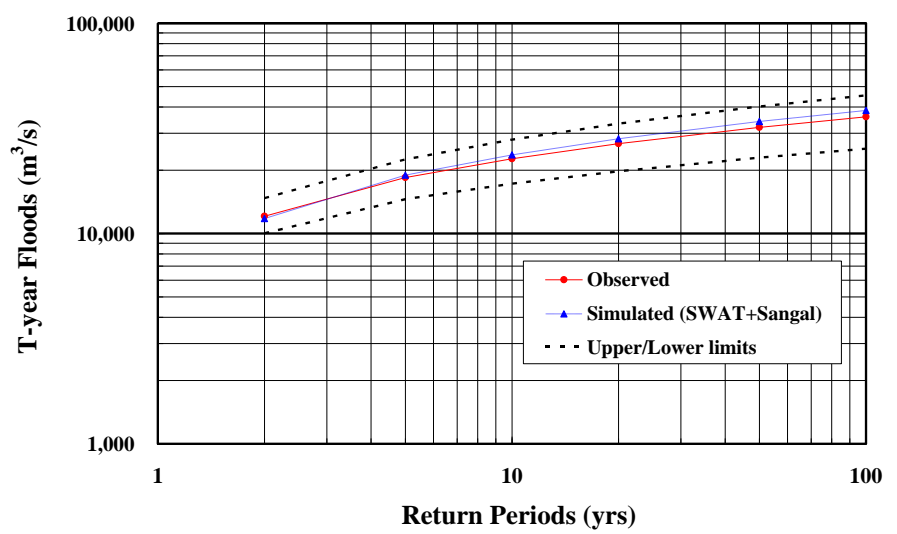

Figure 15. Observed and Simulated Floods for different Return Periods at the Paldang Dam (Hourly). T-year represents the different Return period.

For the same scenarios described in Section 4.2, the effects of dams on peak inflows and flood frequencies on an hourly basis at the Paldang Dam were assessed for conditions with and without dams (Figure 16 and Table 6). The hourly peak flow data were simulated by the procedure mentioned above. A comparison of the flood frequency estimates at the Paldang Dam for the current condition (with the Soyanggang and Chungju dams) and for the condition representing the removal of the Soyanggang Dam (Scenario 1), indicated that the peak inflows increased from $16.0 \%$ to $16.1 \%$ for the 2, $5,10,20,50$ and 100 year return periods. The removal of the Chungju Dam (Scenario 2) caused the peak inflows to increase from $26.0 \%$ to $32.1 \%$. Therefore, Scenario 2 had a greater effect on the peak flow than Scenario 1. The peak flow increment ratio with the removal of both dams (Scenario 3) was slightly lower than the summation of the respective peak flow increment ratios for the removal of the individual dams (Scenarios 1 and 2). 


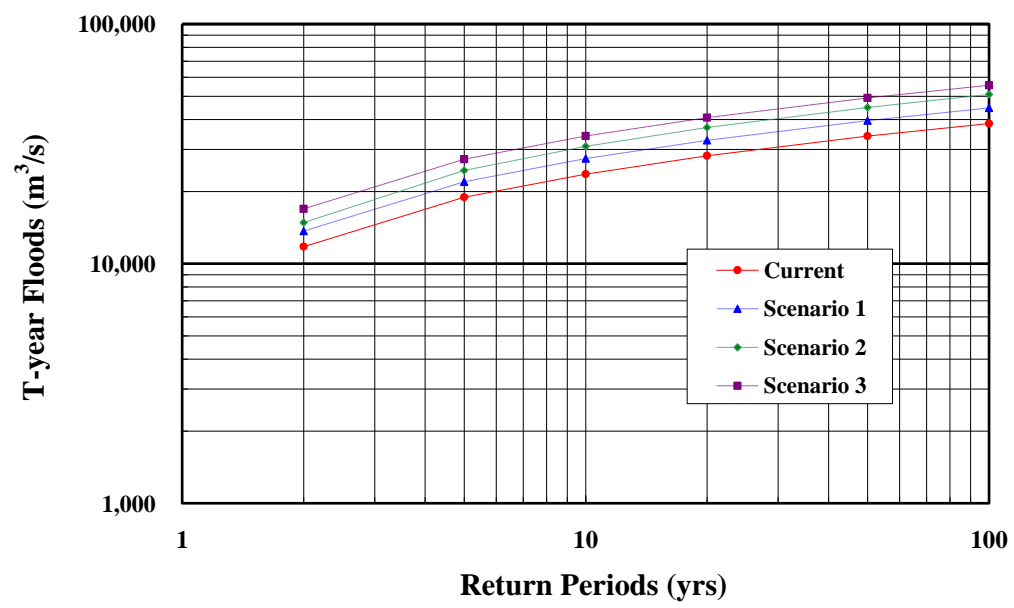

Figure 16. Flood Change for different Return periods according to the Scenarios (Hourly). T-year represents the different return period.

Table 6. Percent Increase in T-year Floods according to the Scenarios (Hourly) (\%).

\begin{tabular}{cccccccc}
\hline \multirow{2}{*}{ Scenarios } & \multicolumn{7}{c}{ Return Periods (Years) } \\
\cline { 2 - 8 } & $\mathbf{2}$ & $\mathbf{5}$ & $\mathbf{1 0}$ & $\mathbf{2 0}$ & $\mathbf{5 0}$ & $\mathbf{1 0 0}$ & Ave. \\
\hline Scenario 1 & 16.0 & 16.1 & 16.1 & 16.1 & 16.1 & 16.1 & 16.1 \\
Scenario 2 & 26.0 & 29.3 & 30.4 & 31.1 & 31.8 & 32.1 & 30.1 \\
Scenario 3 & 43.6 & 44.0 & 44.2 & 44.3 & 44.3 & 44.4 & 44.1 \\
\hline
\end{tabular}

\section{Conclusions}

This study explored the downstream flood frequency alterations caused by dam construction in the Han River basin, South Korea, during 1986-2015 using streamflows simulated by a continuous model, SWAT. The model was used to simulate the long-term peak flows at the Paldang Dam for conditions both with (current state) and without (removal of the Soyanggang Dam or/and the Chungju Dam) upstream dams. Flood frequency curves were established from the simulated annual peak flows for each of these conditions by fitting a series of annual peak flow data to the Extreme Value Type-I distribution. The individual and cumulative effects of upstream dams on the downstream flood frequency were assessed by comparing the developed flood frequency curves. The main conclusions are as follows:

(1) A comparison of the simulated daily peak flows with the observed data indicated that the use of the SWAT model was suitable for estimating the flood frequency. A close correlation $\left(R^{2}=0.903\right.$, RMSE $=0.187 \mathrm{~m}^{3} / \mathrm{s}$ ) between the daily flood estimates for the return periods of 2, 5, 10, 20, 50 and 100 years, computed from the observed and simulated daily inflows to the Paldang Dam, was achieved under the current condition, i.e., with the Soyanggang and Chungju dams in place.

(2) The effect of the Chungju Dam on the flood frequency at the Paldang Dam was found to be greater that of the Soyanggang Dam during the simulation periods. The removal of the Soyanggang Dam (Scenario 1; regulation by the Chungju Dam only) caused an increase in the daily flood peaks by $15.9 \%$, while the removal of the Chungju Dam (Scenario 2; regulation by the Soyanggang Dam only) increased the daily flood peaks by $28.6 \%$.

(3) The peak flow increment ratio by removing both Soyanggang and Chungju dams (Scenario 3) was slightly lower than the summation of the respective peak flow increment ratios from Scenarios 1 and 2.

(4) To overcome the inability of SWAT to reproduce sharp events within hours, a procedure incorporating Sangal's method for estimating instantaneous peak flow from the daily flow 
into the SWAT simulation has been proposed in the present work. As a result of the flood frequency analysis on an hourly basis using this procedure, the errors in the flood estimates were less than $8 \%$, which leads to acceptable accuracy.

(5) The increased average percentage of the hourly flood estimates for the three scenarios, relative to the current state, were $16.1 \%, 30.1 \%$, and $44.1 \%$, for the removals of the Soyanggang, Chungju, and both dams, respectively. These increased percentages were a little higher than those for the estimated daily flood frequencies.

(6) The developed approach allows for a better understanding of flood frequency alterations during the post-dam period, which will improve the applicability of continuous simulation models for the analysis of flood frequency.

Acknowledgments: This research was supported by a grant (code number: 17RDRP-B076272-04) from the Jeju Regional Infrastructure Technology Development Center funded by Ministry of Land, Infrastructure and Transport of the Korean government.

Author Contributions: Jeong Eun Lee performed SWAT modeling as well as flood frequency analysis and wrote the manuscript; Jun-Haeng Heo contributed in-depth analysis of the results and provided editing and writing support; Jeongwoo Lee provided technical advice and writing support; Nam Won Kim developed the methodology and managed the research.

Conflicts of Interest: The authors declare no conflict of interest.

\section{References}

1. Yang, T.; Zhang, Q.; Chen, Y.D.; Tao, X.; Xu, C.; Chen, X. A spatial assessment of hydrologic alteration caused by dam construction in the middle and lower Yellow River, China. Hydrol. Process. 2008, 22, 3829-3843. [CrossRef]

2. Poff, N.L.; Allan, J.D.; Bain, M.B.; Karr, J.R.; Prestegaard, K.L.; Richter, B.D.; Sparks, R.E.; Stromberg, J.C. The natural flow regime. A paradigm for river conservation and restoration. BioScience 1997, 47, 769-784. [CrossRef]

3. Richter, B.D.; Baumgartner, J.V.; Powell, J.; Braun, D.P. A method for assessing hydrologic alteration within ecosystems. Conserv. Biol. 1996, 10, 1163-1174. [CrossRef]

4. Walker, K.F.; Sheldon, F.; Puckridge, J.T. A perspective on dryland river ecosystems. Regul. Rivers Res. Manag. 1995, 11, 85-104. [CrossRef]

5. Gregory, K.J.; Park, C. Adjustment of river channel capacity downstream from a reservoir adjustment of river channel capacity downstream from a reservoir. Water Resour. Res. 1974, 10, 870-873. [CrossRef]

6. Page, K.J. Bankfull Discharge Frequency for the Murrumbidgee River, New South Wales. In Fluvial Geomorphology of Australia; Warner, R.F., Ed.; Academic Press: Sydney, Australia, 1988; pp. 267-281.

7. Galat, D.L.; Lipkin, R. Restoring ecological integrity of great rivers: Historical hydrographs aid in defining reference conditions for the Missouri River Restoring ecological integrity of great rivers: Historical hydrographs aid in defining reference conditions for the Missouri River. Hydrobiologia 2000, 422/423, $29-48$.

8. Maingi, J.K.; Marsh, S.E. Quantifying hydrologic impacts following dam construction along the Tana River, Kenya. J. Arid Environ. 2002, 50, 53-79. [CrossRef]

9. Magilligan, F.J.; Nislow, K.H.; Graber, B.E. Scale-independent assessment of discharge reduction and riparian disconnectivity following flow regulation by dams. Geology 2003, 31, 569-572. [CrossRef]

10. Graf, W.L. Downstream hydrologic and geomorphic effects of large dams on American rivers. Geomorphology 2006, 79, 336-360. [CrossRef]

11. Pegg, M.A.; Pierce, C.L.; Roy, A. Hydrological alteration along the Missouri River Basin: A time series approach. Aquat. Sci. 2003, 65, 63-72. [CrossRef]

12. Batalla, R.J.; Gomez, C.M.; Kondolf, G.M. Reservoir-induced hydrological changes in the Ebro River basin, NE Spain. J. Hydrol. 2004, 290, 117-136. [CrossRef]

13. Magilligan, F.J.; Nislow, K.H. Changes in hydrologic regime by dams. Geomorphology 2005, 71, 61-78. [CrossRef]

14. Singer, M.B. The influence of major dams on hydrology through the drainage network of the Sacramento River Basin, California. River Res. Appl. 2007, 23, 55-72. [CrossRef] 
15. Romano, S.P.; Baer, S.G.; Zaczek, J.J.; Williard, K.W.J. Site modelling methods for detecting hydrologic alteration of flood frequency and flood duration in the floodplain below the carlyle dam, lower Kaskaskia River, Illinois, USA. River Res. Appl. 2009, 25, 975-984. [CrossRef]

16. Hess, G.W.; Inman, E.J. Effects of Urban-Detention Reservoirs on Peak Discharges in Gwinnett County, Georgia; Water-Resources Investigations Report 94-4004; U.S. Geological Survey: Atlanta, GA, USA, 1994.

17. Hess, G.W.; Inman, E.J. Effects of Urban Flood-Detention Reservoirs on Peak Discharges and Flood Frequencies, and Simulation of Flood-Detention Reservoir Outflow Hydrographs in Two Watersheds in Albany, Georgia; Water-Resources Investigations Report 94-4158; U.S. Geological Survey: Atlanta, GA, USA, 1994.

18. Peters, D.L.; Prowse, T.D. Regulation effects on the lower Peace River, Canada. Hydrol. Process. 2001, 15, 3181-3194. [CrossRef]

19. Montaldo, N.; Mancini, M.; Rosso, R. Flood hydrograph attenuation induced by a reservoir system: Analysis with a distributed rainfall-runoff model. Hydrol. Process. 2004, 18, 545-563. [CrossRef]

20. Sayama, T.; Tachikawa, Y.; Takara, K. Assessment of dam flood control using a distributed rainfall-runoff prediction system. In Proceedings of the International Conference on Monitoring, Prediction and Mitigation of. Water-Related Disasters (MPMD2005), Kyoto, Japan, 12-15 January 2005; pp. 59-64.

21. Gross, E.J.; Moglen, G.E. Estimating the Hydrological Influence of Maryland State Dams Using GIS and the HEC-1 Model. J. Hydrol. Eng. 2007, 12, 690-693. [CrossRef]

22. Cameron, D.S.; Beven, K.J.; Tawn, J.; Blazkova, S.; Naden, P. Flood frequency estimation by continuous simulation for a gauged upland catchment (with uncertainty). J. Hydrol. 1999, 219, 169-187. [CrossRef]

23. Calver, A.; Lamb, R. Flood frequency estimation using continuous rainfall-runoff modelling. Phys. Chem. Earth 1995, 20, 479-483. [CrossRef]

24. Blazkova, S.; Beven, K. Flood frequency prediction for data limited catchments in the Czech Republic using a stochastic rainfall model and TOPMODEL. J. Hydrol. 1997, 195, 256-278. [CrossRef]

25. Smithers, J.; Schulze, R.; Kienzle, S. Design Flood Estimation Using a Modelling Approach: A Case Study Using the ACRU Model; IAHS Publication 240; International Association of Hydrological Sciences: Wallingford, UK, 1997; pp. 365-376.

26. Cameron, D.S.; Beven, K.J.; Naden, P. Flood frequency estimation by continuous simulation under climate change (with uncertainty). Hydrol. Earth Syst. Sci. 2000, 4, 393-406. [CrossRef]

27. Cameron, D.S.; Beven, K.J.; Tawn, J.; Naden, P. Flood frequency estimation by continuous simulation (with likelihood based uncertainty estimation). Hydrol. Earth Syst. Sci. 2000, 4, 23-34. [CrossRef]

28. Blazkova, S.; Beven, K. Flood frequency estimation by continuous simulation of subcatchment rainfalls and discharges with the aim of improving dam safety assessment in a large basin in the Czech Republic. J. Hydrol. 2004, 292, 153-172. [CrossRef]

29. Soong, D.T.; Straub, T.D.; Murphy, E.A. Continuous Hydrologic Simulation and Flood-Frequency, Hydraulic, and Flood-Hazard Analysis of the Blackberry Creek Watershed, Kane County, Illinois; Scientific Investigations Report 2005-5270; U.S. Geological Survey: Reston, VA, USA, 2005.

30. Brath, A.; Montanari, A.; Moretti, G. Assessing the effect on flood frequency of land use change via hydrological simulation (with uncertainty). J. Hydrol. 2006, 324, 141-153. [CrossRef]

31. Boni, G.; Ferraris, L.; Giannoni, F.; Roth, G.; Rudari, R. Flood probability analysis for un-gauged watersheds by means of a simple distributed hydrologic model. Adv. Water Resour. 2007, 30, 2135-2144. [CrossRef]

32. Arnold, J.G.; Forher, N. SWAT2000: Current capabilities and research opportunities in applied watershed modeling. Hydrol. Process. 2005, 19, 563-572. [CrossRef]

33. Gassman, P.W.; Reyes, M.; Green, C.H.; Arnold, J.G. The Soil and Water Assessment Tool: Historical development, applications, and future directions. Trans. ASABE 2007, 50, 1211-1250. [CrossRef]

34. Neitsch, S.L.; Arnold, J.G.; Kiniry, J.R.; Williams, J.R. Soil and Water Assessment Tool, Theoretical Documentation, version 2009; Texas Water Resources Institute Technical Report No. 406; Texas Water Resources Institute: College Station, TX, USA, 2011.

35. Ministry of Construction and Transportation. Investigation Report on the Water Supply Capacity of Existing Dams in Han River Basin; Investigation Report DM-97-1; Ministry of Construction and Transportation: Gwacheon, Korea, 1997.

36. Sangal, B.P. Practical method of estimating peak flow. J. Hydraul. Eng. 1983, 109, 549-563. [CrossRef]

37. Kim, N.W.; Lee, J. Temporally weighted average curve number method for daily runoff simulation. Hydrol. Process. 2008, 22, 4936-4948. [CrossRef] 
38. Kim, N.W.; Lee, J. Enhancement of the channel routing module in SWAT. Hydrol. Process. 2010, $24,96-107$. [CrossRef]

39. Nash, J.E.; Sutcliffe, J.V. River flow forecasting through conceptual models part I-A discussion of principles. J. Hydrol. 1970, 10, 282-290. [CrossRef]

40. Hosking, J.R.M. L-moments: Analysis and estimation of distributions using linear combinations of order statistics. J. R. Stat. Soc. Ser. B (Methodological) 1990, 52, 105-124. 